\title{
HUKUM BUNUH DIRI SEORANG WANITA DI TAWAN KHUSUS UNTUK MEMUASKAN NAFSU
}

\author{
Muh. Yunan Putra, Lc., M. HI. \\ Institut Agama Islam (IAI) Muhammadiyah Bima \\ Jln. Anggrek No. 16 Ranggo Na'e Kota Bima \\ mohammed.elgehdy@gmail.com
}

\section{Abstrak}

Beberapa kejadian baru-baru ini seperti peperangan dan perebutan kekuasaan serta wilayah, tampa disadari telah banyak memakan korban dan penghancuran. Entah sudah berapa ribu bangunan hancur dan manusia yang mati dan meninggal dengan mudahnya. Berapa banyak pula manusia yang di tahan dan di tawan serta di siksa. Bagi ummat Islam menyandra bukanlah sesuatu yang di larang apalagi sampai diharamkan, namun ada etika sebagaimana yang diajarkan oleh Allah Swt., dalam surat Al Insan ayat 8 yang artinya: "Dan mereka memberikan makanan yang disukainya kepada orang miskin, anak yatim dan orang yang ditawan." Namun berbeda halnya yang dilakukan oleh para musuh Allah Swt., jangankan memberikan makanan yang disukainya bahkan diberi makanpun sudah luar biasa. Bahkan pada puncaknya, tawanan-tawanan wanita diperkosa dan dijadikan pemuas hawa nafsu. Lalu karena tidak mampu menahan beban tersebut, maka tidak jarang dari para tawanan wanita mengambil keputusan untuk mengakhiri hidup dengan berbagai macam cara. Kalau hanya sehari dua atau seorang dua orang mungkin masih sanggup dihadapi, namun dalam waktu yang tidak jelas dan oleh orang 
banyak, maka inilah yang menjadi masalah yang akan sangat sulit untuk dijalani. Lalu bagaimana hukumnya menurut Islam tentang wanita-wanita yang mengakhiri hidup tersebut, apakah tergolong dosa besar bagi yang mengakhiri hidup dalam keadaan demikian. Maka inilah yang hendak penulis rangkum dan jelaskan dengan harapan tulisan ini memberikan manfaat dan ilmu pengetahuan bagi penulis sendiri dan para pembaca.

\section{Keyword: Hukum, Tawan, Bunuh Diri, Perkosa, Terpaksa.}

\section{A. Pendahuluan}

Setiap makhluk yang diciptakan oleh Allah SWT. mimiliki hak asasi masing-masing; baik itu berupa binatang, tumbuh-tumbuhan dan lebih-lebih makhluk yang bernama manusia. Allah Swt. berfirman:

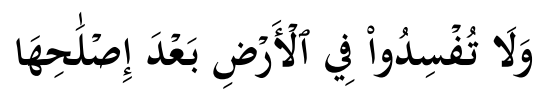

Terjemahnya:

"Dan janganlah kamu membuat kerusakan di muka bumi, sesudah (Allah) memperbaikinya". (Qs. Al A'raf ayat 56)

Larangan ini walaupun bersifat tidak mutlaq (artinya, adakalanya dibolehkan dengan syarat menggatinya dengan susuatu yang lebih baik), ${ }^{1}$ namun yang pasti terdapat larangan merusak ciptaan Allah Swt. Hal ini ternyata tidak hanya berlaku dalam keadaan normal, bahkan dalam keadaan perang sekalipun dilarang. Abu Bakar al Shiddiq, ketika mengutus para mujahid untuk berperang di Syam berpesan, "Jangan sekali-kali menebang pohon kurma, jangan pula membakarnya, jangan

${ }^{1}$ Lihat: Abdullah bin Muhammad bin Abdurrahman bin Ishaq al Sheikh. 2005. Tafsir Ibnu Katsir Juz III, Tajm. M. Abdul Ghaffar dkk. Cetakan IV. Jakarta, Pustaka Imam Syafi'i. Hlm. 393-395. 
membunuh hewan-hewan ternak, jangan tebang pohon yang berbuah, janganlah kalian merobohkan bangunan,..." (HR. Al Baihaqi, Ibnu Asakir dan Al Thahawi). ${ }^{2}$ Maka kalaulah seperti itu memperlakukan tumbuhan dan binatang, apalagi kepada manusia yang pada hakikat penciptaannya lebih sempurna dan lebih mulia dari makhluk lain.

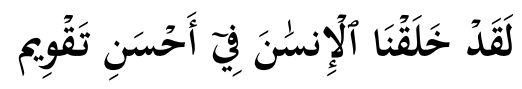

Terjemahnya:

"Sesungguhnya Kami telah menciptakan manusia dalam bentuk yang sebaik-baiknya." (QS. Al Tin: 4)

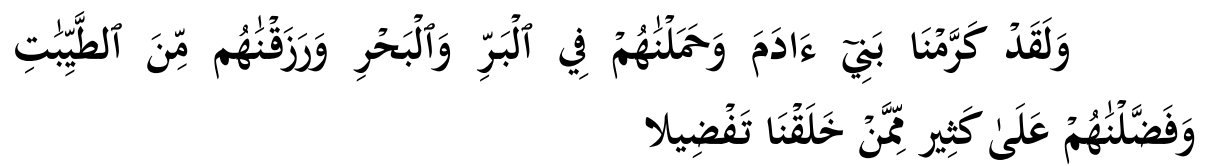

Terjemahnya:

"Dan sesungguhnya telah Kami muliakan anak-anak Adam, Kami angkut mereka di daratan dan di lautan, Kami beri mereka rezeki dari yang baik-baik dan Kami lebihkan mereka dengan kelebihan yang sempurna atas kebanyakan makhluk yang telah Kami ciptakan." (QS. Al Isra': 70)

Dari beberapa kejadian, sebut saja di Bosnia Herzegofina, kemudian di Palestina yang hingga kini masih bergejolak, lalu Surya Irak, di Myanmar, di Ugyur Cina dan yang baru-baru ini sedang terjadi di India. Entah sudah berapa banyak bangunan hancur dan nyawa melayang, hak asasi manusia di rampas dan dikebiri. Tidakkah para musuh Allah ini berpikir sejenak bagaimana kalau seandainya keluarga atau mungkin pribadinya sendiri yang diperlakukan demikian.

${ }^{2}$ Lihat: Sunanul Kubra karangan Al-Baihaqi hadits no. 17904, Tarikh Dimasyq karangan Ibnu Asakir Julid II hadits no. 75, dan Syarah Musykilul Atsar karangan Al Thahawi jilid III hadits no. 144.

Sangaji Jurnal Pemikiran Syariah dan Hukum 
Dalam setiap peperangan dan perluasan wilayah, selalu ada yang namanya tawanan perang. Tawanan dalam Islam adalah sama derajat dan hak-nya dengan orang merdeka; tetap dihormati, di beri makan dan di jaga. Namun berbeda jauh dengan perlakuan para musuh-musuh Allah Swt., yang katanya menjunjung tinggi harkat dan martabat manusia. Para tawanan diperlakukan seperti binatang, di siksa dan di bunuh apabila melawan. Lalu para tawanan wanitanya dirampas kehormatannya, di perkosa bergilir hari demi hari, waktu demi waktu kapan diinginkan.

Maka tidak jarang dari beberapa tawanan wanita mengakhiri hidup dengan berbagai macam cara karena merasa tidak mampu lagi untuk bertahan, waktu yang tidak pasti kapan akan berakhirpun tidak ada, belum lagi beban psikoligi serta trauma yang mendalam dalam hati dan diri yang pada akhirnya mengandung dan melahirkan anak dari benih yang salah dan cara yang tidak diridhai oleh Allah Swt.

\section{B. Pembahasan}

\section{Pengertian Bunuh Diri}

Bunuh diri atau yang dalam bahasa arabnya biasa

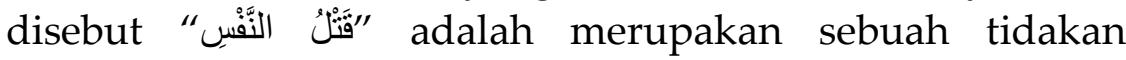
mengakhiri hidup dengan menggunakan atau tampa menggunakan alat. Imam Shalahuddin Al Jalili mendefinisikan bunuh diri adalah membunuh diri sendiri yang juga merupakan gambaran dari keputusasaan yang sudah mencapai titik klimaks. Sepertinya, sudah tidak ada harapan hidup lagi, juga tidak ada kebahagiaan yang bisa diraih. Karena itu bunuh diri sebagai jalan keluarnya. ${ }^{3}$

${ }^{3}$ Muhammad Anas. 2015. Bunuh Diri Menurut Emile Durkhem Dalam Pandangan Agama Islam dan Pencegahannya. Jurnal Review Pendidikan Islam, Volume 02, Nomor 01, Juni 2015. Hlm. 168. 
Sedangkan DR. Kartono Kartini (Psikiater Senior) dalam Hygiene Mental mendefinisikan Bunuh Diri sebagai berikut: ${ }^{4}$

a) Bunuh diri adalah perbuatan dengan sengaja dengan bertujuan secara sadar mengambil nyawa sendiri.

b) Bunuh diri adalah perbuatan manusia yang disadari dan bertujuan untuk menyakiti diri sendiri dan menghentikan kehidupan sendiri. Dalam kalimat ini ada 5 hal yang penting, yaitu diantaranya;

1) Merupakan perbuatan manusia,

2) Ada keinginan yang disadari untuk mati,

3) Memiliki motivasi-motivasi tertentu,

4) Bertujuan menggapai kematian,

5) Ada introspeksi penuh kesadaran mengenai satu konsep tentang kematian atau penghentian kehidupan.

c) Bunuh diri adalah pembunuhan secara simbolis, karena ada peristiwa identifikasi dengan seorang yang dibenci dengan membunuh diri sendiri orang yang bersangkutan secara simbolis membunuh orang yang dibencinya.

d) Bunuh diri adalah satu jalan untuk mengatasi macammacam kesulitan pribadi, berupa rasa kesepian, dendam, takut, kesakitan fisik, dosa, dan lain-lain.

e) Bunuh diri adalah prakarsa/inisiasi perbuatan yang mengarah pada kematian pemrakarsa.

f) Bunuh diri adalah keinginan yang mendorong suatu perbuatan untuk melakukan destruksi/pengrusakan diri sendiri.

4 Muhammad Anas. 2015. Bunuh Diri Menurut Emile Durkhem Dalam Pandangan Agama Islam dan Pencegahannya. Jurnal Review Pendidikan Islam, Volume 02, Nomor 01, Juni 2015. Hlm. 168-170.

Sangaji Jurnal Pemikiran Syariah dan Hukum 
g) Bunuh diri adalah inisiasi perbuatan yang mengarah pada motivasi kematian, membunuh dan dibunuh.

h) Bunuh diri merupakan keadaan hilangnya kemauan untuk hidup.

i) Bunuh diri ialah satu derajat sentral dari keputusan pelaku yang memutuskan untuk memprakarsai satu perbuatan mengarah pada kematian sendiri.

j) Bunuh diri adalah derajat ketegasan dan ketegaran keputusan untuk memprakarsai perbuatan yang mengarah pada kematian sendiri.

k) Bunuh diri adalah kemauan berbuat mengarah pada kematian sendiri.

1) Bunuh diri adalah derajat efektivitas satu perbuatan yang disengaja dan bertujuan, yang mengakibatkan kematian.

m) Bunuh diri adalah pengetahuan seorang mengenai relasi dirinya dengan kondisi obyektif dan kematian.

Maka dari uraian pengertian di atas, penulis menyimpulkan bahwa bunuh diri adalah suatu tindakan yang melampaui batas dan menyalahi takdir yang telah ditetapkan oleh Allah Swt.

\section{Faktor Penyebab Bunuh Diri}

Terdapat banyak faktor yang dapat mengakibatkan seseorang melakukan bunuh diri, diantaranya yaitu: ${ }^{5}$

a) Adanya gangguan psikologis. Gangguan psikologis dapat menimbulkan tindakan-tindakan berbahaya, baik itu merupakan tindakan bunuh diri yang mematikan, maupun bunuh diri yang tidak mematikan. Depresi dan

${ }^{5}$ Mawaddah Nasution. 2017. Pendidikan Agama dan Kasus Bunuh Diri Di Kalangan Remaja. Prosiding Seminar Hilirisasi Penelitian Untuk Kesejahteraan Masyarakat Lembaga Penelitian Universitas Negeri Medan, 28 September 2017. Hlm. 402-403. 
skizophrenia merupakan gangguan psikologis yang sering berkaitan dengan percobaan bunuh diri. dalam studi yang digelar pada tahun 1990, ditemukan bahwa dari $60 \%$ laki-laki dan $44 \%$ perempuan yang melakukan percobaan bunuh diri menderita depresi. Selain itu antara $30 \%$ sampai $50 \%$ penderita skizophrenia minimal sekali melakukan percobaan bunuh diri.

b) Penggunaan alkohol dan narkotik (Substance Abuse). Penggunaan alkohol dan narkotik merupakan faktor yang sangat penting dalam percobaan bunuh diri, hal ini dapat di lihat dari berbagai penelitian yang menunjukkan bahwa penggunaan narkotik dan obatobatan lainnya ikut ambil bagian dalam kasus bunuh diri dengan 18 prosentase antara $25 \%$ sampai $55 \%$.

c) Krisis kepribadian (Personality Disorder). Meskipun hubungan antara krisis kepribadian dan bunuh diri belum diyakini secara umum, tapi beberapa penelitian terkini menunjukkan bahwa krisis kepribadian merupakan faktor penting dalam melakukan percobaan bunuh diri. Penyakitpenyakit jasmani termasuk hal-hal yang paling sering mengakibatkan bunuh diri, khususnya bagi orang-orang tua. Rasa sakit merupakan faktor penting dalam sekitar $20 \%$ dari kasus bunuh diri yang dilakukan orang-orang tua. Banyak riset yang mengkaji hubungan antara penyakit jasmani yang kronis dan bunuh diri.

d) Faktor-faktor genetis (Genetic Factors). Para pakar yang akhir-akhir ini meneliti bunuh diri secara biologis menyatakan bunuh diri memiliki kesiapan-kesiapan genetis. Meskipun tindakan bunuh diri yang dilakukan salah satu anggota keluarga atau kerabat bukanlah sebab langsung bagi bunuh diri, namun para anggota keluarga

Sangaji Jurnal Pemikiran Syariah dan Hukum 
ini lebih rentan terhadap bunuh diri dari pada yang lain. Hal ini mengacu pada kenyataan bahwa depresi dan penyakit-penyakit lainnya.

e) Perubahan dalam dunia kerja (Labour Market). Revolusi ekonomi dan teknologi yang terjadi di dunia telah membawa dampak positif dan negatif, disengaja dan tidak sengaja, baik dalam bidang ekonomi, sosial, kejiwaan, politik dan budaya. Semua ini mempengaruhi kesehatan penduduk dunia, diantara permasalahan serius yang dihadapi dunia secara bersama adalah semakin bertambahnya jumlah pengangguran. Krisis moneter dan ekonomi di dunia mengakibatkan bertambahnya pengangguran dan menimbulkan bahaya yang serius.

f) Kondisi keluarga. Kebanyakan remaja yang memiliki prilaku bunuh diri menghadapi berbagai problem keluarga yang membawa kepada kebimbangan tentang harga diri, serta menumbuhkan perasaan bahwa tidak disukai, tidak diperlukan, tidak dipahami dan tidak dicintai. Mayoritas berasal dari keluarga yang menerapkan sistem pendidikan yang tidak layak. Biasanya para orang tua yang berada disekitar anak berlaku keras terhadapnya, mengabaikannya, atau hanya memperhatikan pertumbuhan fisiknya saja dan bukan perilakunya. Hilangnya cinta kadang ikut berperan bagi perkembangan bahaya bunuh diri. Kehilangan cinta ini bisa terjadi karena faktor kematian, perceraian, atau menurunnya kasih 20 sayang orantua dan orang-orang yang memiliki kedudukan penting dalam kehidupan seseorang.

g) Pengaruh media massa. Berita tentang bunuh diri kadang dapat memicu tindakan bunuh diri, terutama bagi orang-orang yang memang telah mempersiapkan 
diri untuk melakukannya. Ketika tahu bahwa orang yang mati bunuh diri sebelumnya hidup dengan posisi dan keadaan yang sama dengan yang dialami, maka itu bisa mendorong untuk meniru dan melakukan perbuatan yang sama

Sedangkan Muhammad Adam Hussein dalam hal ini mempunyai pendapat. Dimana faktor penyebab bunuh diri itu disebabkan oleh beberapa motif, sebagai berikut: ${ }^{6}$

a) Depresi (Pengaruh dari pikiran yang macam-macam, sehingga arah pikiran menjadi kacau, saking kacaunya sehingga tak mampu berpikir jernih.)

b) Tekanan Emosi (Terlalu menuntut ini itu terhadap diri sendiri, sedang kemampuan diri tidak bisa menjangkaunya hingga akhirnya emosi terpendam. Saking terpendamnya emosi semakin lama semakin menumpuk yang akhirnya mengakibatkan keputusasaan tingkat tinggi hingga muncul tindakan percobaan bunuh diri.)

c) Tidak berani menghadapi kenyataan hidup (Banyak hal yang terjadi dalam hidup ini yang tidak sesuai dengan keinginan atau harapan hingga menutupi kebenaran/kenyataan hidup, sikap seperti ini sikap lari dari masalah, padahal perlu diketahui masalah tidak bisa dihindarkan dalam hidup ini.)

d) Miskin Harta, Miskin Ilmu, dan Miskin Iman (Miskin Harta dimana kebutuhan hidup tidak terpenuhi dengan semestinya. Miskin Ilmu, dimana saat ilmu yang ingin dikuasai kerapkali tidak berhasil dipelajari. Miskin Iman, maksudnya kurang pemahaman tentang ajaran agama juga dapat menjadi faktor penyebab bunuh diri.)

${ }^{6}$ Muhammad Anas. 2015. Bunuh Diri Menurut Emile Durkhem Dalam Pandangan Agama Islam dan Pencegahannya. Jurnal Review Pendidikan Islam, Volume 02, Nomor 01, Juni 2015. Hlm. 177-178.

Sangaji Jurnal Pemikiran Syariah dan Hukum 
e) Penyalahgunaan Barang Haram (Terlalu kecanduan atau ketergantungan terhadap barang haram seperti sabusabu, alkohol, dan barang haram lainnya yang memabukkan. Itu semua dapat memicu untuk berbuat nekad termasuk berani bunuh diri.)

Dua pendapat di atas, tentang faktor terjadinya usaha bunuh diri sebenarnya hampir sama dan saling melengkapi, namun penulis belum menemukan secara spesifik atau secara eksplisit terkait pembahasan yang sedang di jelaskan oleh penulis sendiri.

\section{Bunuh Diri Dalam Keterpaksaan}

Pada faktor penyebab terjadinya usaha bunuh diri yang diungkapkan oleh Muhammad Adam Hussein pada point a dan c, sebenarnya hampir mengenai pembahasan yang di angkat oleh penulis, namun masih belum mengenai secara keseluruhan. Muhammad Adam Hussein hanya menjelaskan tentang depresi yang di alami oleh seseorang dan ketidakmampuannya dalam menghadapi kenyataan hidup, seperti keinginan yang tidak sesuai dengan harapan. Maka bagaimana hukumnya dalam agama Islam ketika terjadi hal yang diangkat oleh penulis, dimana seseorang mengakhiri hidupnya dengan alasan keterpaksaan serta keadaan yang menimpa dan di jalani olehnya tampa ia sendiri tidak mengetahui kapan berakhirnya.

Jika melihat dan membuka kembali beberapa firman Allah Swt., maka akan ditemukan beberapa ayat yang menjelaskan tentang bolehnya melakukan sesuatu yang diharamkan sekalipun dalam keadaan terpaksa, seperti contohnya: makan bangkai dalam keadaan tiada lagi makanan lain yang boleh di makan. Allah Swt. Berfirman dalam beberapa ayat-Nya: 


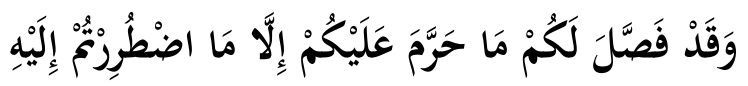

Terjemahnya:

"Dan sesungguhnya Allah telah menjelaskan kepada kalian apa yang Dia haramkan, kecuali yang terpaksa kalian makan." (QS. Al An'am: 119)

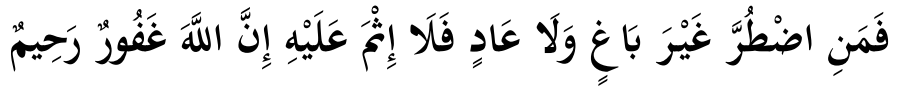

Terjemahnya:

"Siapa yang dalam kondisi terpaksa memakannya sedangkan ia tidak menginginkannya dan tidak pula melampaui batas, maka ia tidak berdosa. Sesungguhnya Allah Maha pengampun lagi Maha penyayang". (QS. Al Baqarah: 173)

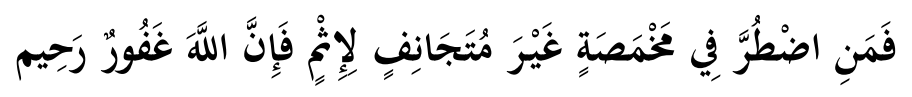

Terjemahnya:

"Siapa yang terpaksa mengonsumsi makanan yang diharamkan karena lapar, bukan karena ingin berbuat dosa, maka sungguh Allah Maha Pengampun lagi Maha Penyayang". (QS. Al Ma'idah: 3)

Begitu juga dengan penjelasan yang diberikan oleh Rasulullah Saw., ketika beliau di tanya oleh seorang sahabat tentang membunuh seseorang yang mengambil hartanya. Seorang lelaki yang bertanya kepada Rasulullah Saw., "Apa pendapatmu apabila seseorang ingin mengambil hartaku?" Beliau menjawab, "Jangan engkau berikan hartamu." Lelaki itu kembali bertanya, "Lalu bagaimana jika ia ingin membunuhku?" Beliau pun menjawab, "Bunuh dia." "Jika ia berhasil membunuhku?" tanyanya lagi. "Maka engkau mati syahid," jawab Rasulullah. Lagi-lagi ia bertanya, "Jika aku yang membunuhnya?" Rasulullah menjawab, "Dia berada di 
neraka. (HR. Bukhari, haditsno. 6888, dan Muslim, hadits no. 2158).

Maka dari dua dalil dari Al Quran dan hadits di atas, dapat di ambil sebuah kesimpulan awal bahwa dibolehkannya melakukan atau mengonsumsi sesuatu yang jelas-jelas di haramkan oleh Allah Swt. dan Rasul-Nya ketika dalam keadaan darurat atau terpaksa.

Selanjutnya, apa sebenarnya makna darurat yang dimaksudkan oleh Allah Swt. dalam ayat di atas, apakah segala jenis darurat atau memang sudah di tetapkan bentuk dan jenisnya?. Maka perlu di kaji terlebih dahulu pendapat beberapa ulama terkait pengertian darurat yang di maksud.

a) Pengertian darurat atau dalam bahasa arabnya dharurah menurut Jalaluddin al Suyuthi adalah seseorang mencapai batas bila tidak memakan sesuatu yang dilarang, maka ia akan mati atau mendekati mati. Dan kondisi ini membolehkannya memakan barang haram. ${ }^{7}$

b) Wahbah al Zuhaily berpendapat bahwa darurat adalah suatu kemaslahatan yang menjadi landasan hidup manusia secara alamiah agama atau dunia yang sekiranya sesuatu tersebut ditiadakan maka tidak akan mampu bertahan hidup di muka bumi ini dan lebih parahnya lagi akan terjadi beberapa kerusakan diantaranya terbengkalainya beberapa nikmat dan akhirnya siksalah yang bakal diterima kelak di akhirat. ${ }^{8}$

c) Ibnu Nujaim mengartikan bahwa darurat adalah sampainya seseorang kepada suatu batas yangapabila

7 Jalaluddin al Suyuthi. 1403 H. Al Asybah wa al Nazha'ir. Beirut: Dar al Kutub al Ilmiyah. Hlm. 60-61.

8 Wahbah Zuhaili. 1996 Ushul Figh Al Islami. Damaskus: Dar al Fikri. Hlm. 1020. 
tidak melakukan sesuatu perbuatan yang dilarang akan dapat mencelakakan dirinya. ${ }^{9}$

d) Sedangkan, Abu Zahrah, sebagai ahli ushul fiqh dan kalam, mendefinisikan darurat sebagai suatu keadaan yang memaksa untuk memakan yang di larang dalam rangka mempertahankan nyawa, khawatir akan kehilangan harta atau karena kebutuhan dharuri (pokok) seseorang terancam apabila dia tidak mempertahankannya kecuali dengan melakukan sesuatu yang dilarang tanpa mengganggu hak orang lain. ${ }^{10}$

Dengan melihat beberapa pendapat ulama terkait pengertian darurat di atas, maka dapat di tarik beberapa syarat dan ketentuan sesuatu dikatakan darurat sehingga membolehkan melakukan sesuatu yang sebelumnya diharamkan: ${ }^{11}$

a) Darurat tersebut benar-benar terjadi atau diprediksi kuat akan terjadi, tidak semata-mata praduga atau asumsi belaka. Contohnya, seorang musafir di tengah perjalanan merasa sedikit lapar karena belum makan siang. Padahal ia akan tiba di tempat tujuan sore nanti. Maka tidak boleh mencuri dengan alasan jika tidak makan siang ia akan mati, karena alasan yang dikemukakan hanya bersandar pada prasangka semata.

b) Tidak ada pilihan lain yang bisa menghilangkan mudarat tersebut. Contohnya, seorang musafir kehabisan bekal di tengah padang pasir. Ia berada dalam kondisi lapar yang sangat memprihatinkan. Di tengah

${ }^{9}$ Abdul Aziz Dahlan. 1997. Ensiklopedia Hukum Islam. Cetakan I. Jakarta: PT. Ihtiar Baru Van Hoeven. Hlm. 327.

${ }^{10}$ Kafawi Ridwan, et al. 1993. Ensiklopedia Islam. Jakarta, PT. Icgtiar Baru van Hoeven. Hlm. 293.

11 Al Sadlan dan Shalih bin Ghanim. 1418 H. Cetakan I. Al Qawaid al Fiqhiyyah al Kubra wa Ma Tafarra'a 'Anh. Riyadh: Dar Balnasiyah. Hlm. 250-251

Sangaji Jurnal Pemikiran Syariah dan Hukum 
perjalanan, bertemu seorang pengembala bersama kambing kepunyaannya. Tak jauh dari tempatnya berada terlihat bangkai seekor sapi. Maka tak boleh memakan bangkai sapi tersebut karena bisa membeli kambing atau memintanya dari si pengembala.

c) Kondisi darurat tersebut benar-benar memaksa untuk melakukan hal yang diharamkan karena dikhawatirkan kehilangan nyawa atau anggota badannya.

d) Keharaman yang dilakukan tersebut tidak menzhalimi orang lain. Contohnya, Jika seseorang dalam keadaan darurat dan terpaksa dihadapkan dengan dua pilihan: memakan bangkai atau mencuri makanan, maka hendaknya memilih memakan bangkai. Hal itu dikarenakan mencuri termasuk perbuatan yang menzhalimi orang lain. Kecuali jika tidak memiliki pilihan selain memakan harta orang lain tanpa izin, maka diperbolehkan dengan syarat harus tetap menggantinya.

e) Tidak melakukannya dengan melewati batas. Cukup sekadar yang diperlukan untuk menghilangkan mudarat. Contohnya, Seorang dokter ketika mengobati pasien perempuan yang mengalami sakit di tangannya, maka boleh baginya menyingkap aurat sebatas tangannya saja. Tidak boleh menyingkap aurat yang tidak dibutuhkan saat pengobatan seperti melepas jilbab, dan lain sebagainya. Sama halnya dengan orang yang sangat kelaparan di tengah perjalanan. Maka boleh memakan bangkai sekadar untuk menyambung hidupnya saja. Dengan kata lain tidak boleh mengonsumsinya hingga kenyang, melewati kadar untuk menghilangkan mudarat yang dialaminya.

Maka dari pengertian dan persyaratan yang di ungkapkan oleh para ulama di atas dapat di tarik 
kesimpulan kedua bahwa bolehnya melakukan sesuatu yang diharamkan sebelumnya adalah ketika dalam keadaan darurat dengan beberapa ketentuan, yang singkat penulis menyimpulkan bahwa hendaknya perbuatan yang dilakukan tersebut tidak lebih berat mudahratnya (lebih ringan) dari yang ditinggalkan.

Hal ini sesuai dengan kaidah yang ungkapkan oleh ulama, bahwa:

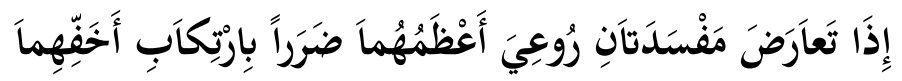

Artinya:

"Jika dihadapkan pada dua mafsadat (kerusakan/yang membinasakan), maka mafsadat yang lebih besar harus dihindari dengan cara mengambil mafsadat yang lebih ringan."

Maka apabila kembali kepada pokok pembahasan, tentang hukum mengakhiri hidup dengan alasan dijadikan sebagai tawanan perang dan pemuas nafsu para musuhmusuh Allah Swt. dan Rasul-Nya, akan sampai kepada kesimpulan akhir bahwa hal tersebut tetaplah diharamkan. Hal terebut dengan alasan:

a) Dalil dari Al Quran

\section{Dalil Pertama}

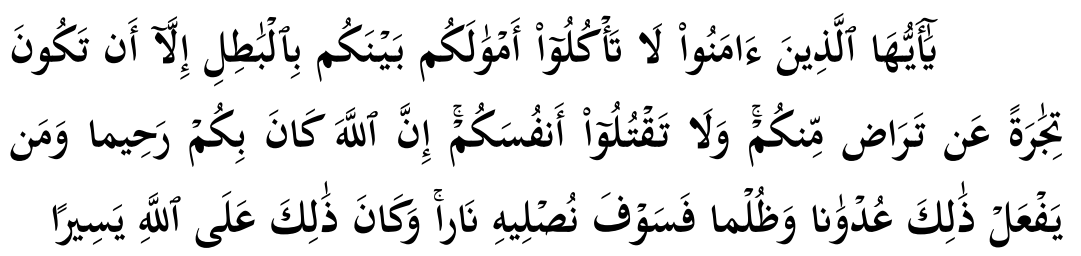

Terjemahnya:

"Hai orang-orang yang beriman, janganlah kamu saling memakan harta sesamamu dengan jalan yang batil, kecuali dengan jalan perniagaan yang berlaku dengan suka sama-suka di antara kamu. Dan janganlah kamu membunuh

Sangaji Jurnal Pemikiran Syariah dan Hukum 
dirimu; sesungguhnya Allah adalah Maha Penyayang kepadamu. Dan barangsiapa berbuat demikian dengan melanggar hak dan aniaya, maka Kami kelak akan memasukkannya ke dalam neraka. Yang demikian itu adalah mudah bagi Allah. (QS. Al Nisa': 29-30)

Dalam ayat ini Allah Swt., menjelaskan dengan langsung memberikan ganjaran akibat perbuatan tersebut, yaitu dimasukkannya ke dalam neraka. Artinya mafsadat atau mudharat dari melakukan bunuh diri itu lebih besar dari apa yang ia terima terhadap perlakuan musuh-musuh Allah Swt. tersebut. Oleh karenanya dalam ayat lain Allah Swt., menjelaskan:

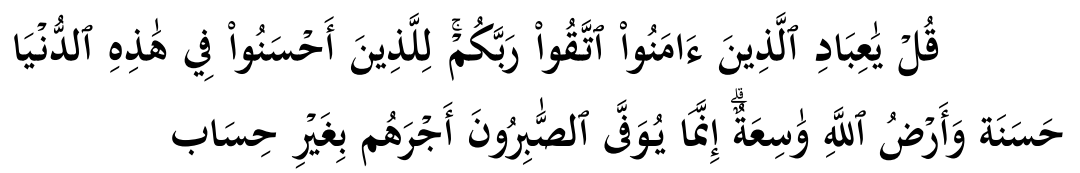

Terjemahnya:

"Katakanlah: "Hai hamba-hamba-Ku yang beriman. bertakwalah kepada Tuhanmu". Orang-orang yang berbuat baik di dunia ini memperoleh kebaikan. Dan bumi Allah itu adalah luas. Sesungguhnya hanya orang-orang yang bersabarlah Yang dicukupkan pahala mereka tanpa batas." (QS. Al Zumar: 10)

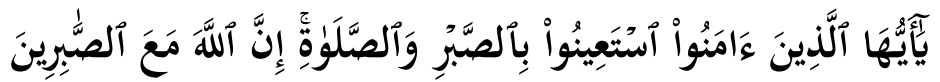

Terjemahnya:

"Hai orang-orang yang beriman, jadikanlah sabar dan shalat sebagai penolongmu, sesungguhnya Allah beserta orang-orang yang sabar." (QS. Al Baqarah: 153)

\section{Dalil Kedua}

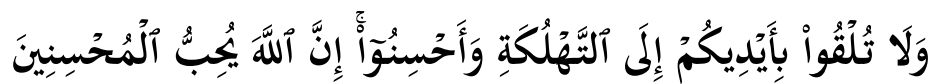


Terjemahnya:

"Dan janganlah kamu menjatuhkan dirimu sendiri ke dalam kebinasaan, dan berbuat baiklah, karena sesungguhnya Allah menyukai orang-orang yang berbuat baik." (QS. Al Baqarah: 195)

Dalam ayat ini Allah Swt., melarang para hambaNya untuk menjerumuskan dirinya dalam kebinasaan, maka kebinasaan di sini bisa berupa perbuatan yang hanya mencederai anggota tubuhnya dan bisa juga berarti perbuatan yang merenggut nyawa.

b) Dalil dari Hadits

\section{Hadits Pertama}

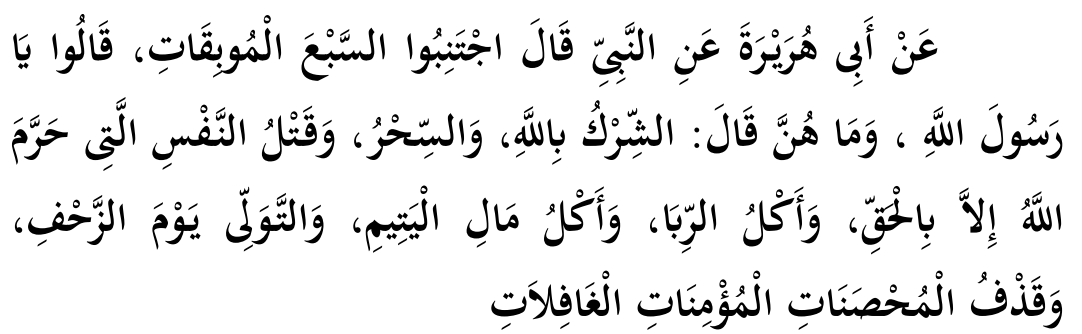

Artinya:

Dari Abu Hurairah, dari Nabi Saw., beliau bersabda, "Jauhilah tujuh dosa yang membinasakan." Mereka berkata, "Wahai Rasulullah, apa saja dosa yang membinasakan tersebut?" Beliau bersabda, "(1) Syirik kepada Allah, (2) sihir, (3) membunuh jiwa yang haram untuk dibunuh kecuali jika lewat jalan yang benar, (4) makan riba, (5) makan harta anak yatim, (6) lari dari medan perang, (7) qadzaf (menuduh wanita mukminah yang baik-baik dengan tuduhan zina)." (HR. Bukhari, hadits no. 2766 dan Muslim, hadits no. 89) 


\section{Hadits Kedua}

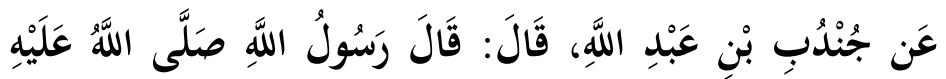

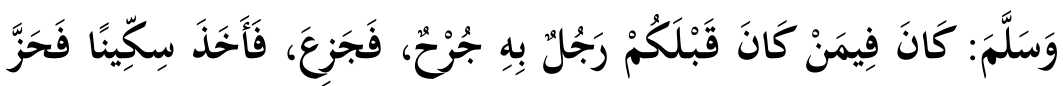

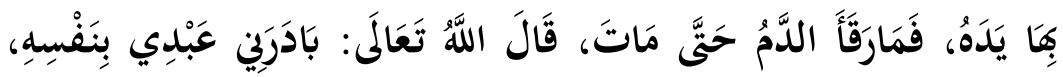
حَرَّمْتُ عَلَيْهِ الجنَّنَُّ

Artinya:

Dari Jundub bin Abdullah, dia berkata: Rasulullah Saw. bersabda, "Dahulu ada seorang laki-laki sebelum kamu yang mengalami luka, lalu dia berkeluh kesah, kemudian dia mengambil pisau, lalu dia memotong tangannya. Kemudian darah tidak berhenti mengalir sampai dia mati. Allâh Azza wa Jalla berfirman, 'Hamba-Ku mendahului-Ku terhadap dirinya, Aku haramkan surga baginya". (HR. Al-Bukhari, hadits no. 3463)

\section{Hadits Ketiga}

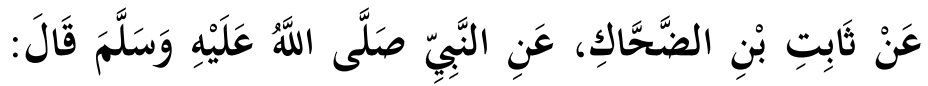

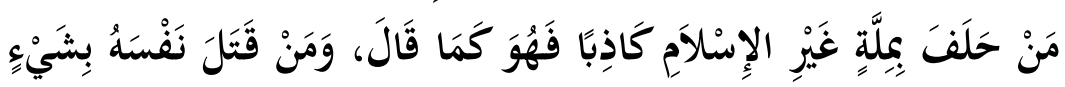

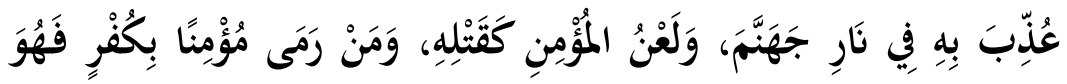
كَقَتْلِهِ

Artinya:

Dari Tsabit bin al Dhahhak, dari Nabi Saw, beliau bersabda, "Barangsiapa bersumpah dengan agama selain Islam dalam keadaan dusta, maka dia sebagaimana yang dia katakan. Barangsiapa membunuh dirinya dengan sesuatu, dia akan disiksa dengan sesuatu itu dalam neraka Jahannam. Melaknat seorang Mukmin seperti membunuhnya. Dan barangsiapa menuduh seorang Mukmin dengan kekafiran 
maka itu seperti membunuhnya". [HR. Al Bukhari, hadits no. 6105 dan 6652, Ahmad, hadits no. 16391; lafazh ini dari Al-Bukhâri]

\section{Hadits Keempat}

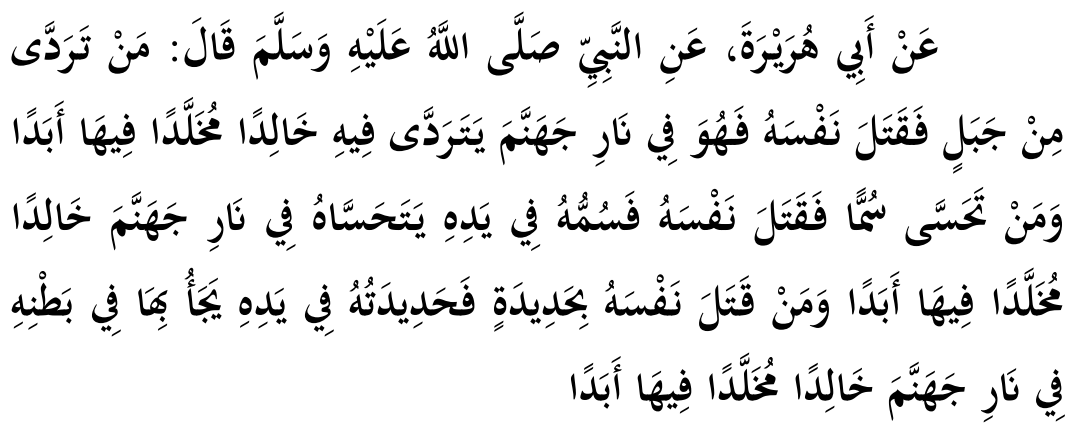

Artinya:

Dari Abu Hurairah, dari Nabi Saw, Beliau bersabda, "Barangsiapa menjatuhkan dirinya dari sebuah gunung, kemudian membunuh dirinya, maka dia di dalam neraka Jahannam menjatuhkan dirinya dari sebuah gunung, dia tinggal lama dan dijadikan tinggal lama selamanya di dalam neraka Jahannam selama-lamanya. Dan barangsiapa meminum racun kemudian membunuh dirinya, maka racunnya akan berada di tangannya, dia akan meminumnya di dalam neraka Jahannam dia tinggal lama dan dijadikan tinggal lama selamanya di dalam neraka Jahannam selamalamanya.Dan barangsiapa membunuh dirinya dengan besi, maka besinya akan berada di tangannya, dia akan menikam perutnya di dalam neraka Jahannam, dia tinggal lama dan dijadikan tinggal lama selamanya di dalam neraka Jahannam selama-lamanya". (HR. Al Bukhari, hadits no. 5778; Muslim, hadits no. 109; lafazh Al-Bukhari)

Oleh kerasnya larangan dan balasan yang ditimpakan oleh Allah Swt., maka tiada alasan bagi seseorang yang mengakhiri hidupnya dengan cara 
bunuh diri dengan apapun alasannya. Karena besarnya alasan untuk melakukan perbuatan tersebut tidak sebanding dengan apa yang akan ia rasakan ketika berhadapan Allah Swt., di hari yang dijanjikannya kelak. Wallahu a'lam.

\section{Penutup}

Dari penjelasan yang telah dipaparkan oleh penulis di atas, maka dapat ditarik beberapa kesimpulan:

1. Manusia adalah mahluk Allah Swt., yang paling sempurna penciptaannya dibading dengan makhluk-makhluk lain, hal tersebut sebagaimana dijelaskan dalam Surat $\mathrm{Al}$ Tin ayat 4 dan Surat Al Isra' ayat 70.

2. Hak asasi dalam Islam tidak hanya dimiliki oleh manusia, namun makhluk Allah Swt., yang lain-pun memiliki hak asasi masing-masing yang harus diketahui oleh masnusia, hal tersebut sebagaimana firman Allah Swt., dalam surat $\mathrm{Al}$ A'raf ayat 56 dan hadits yang diriwayatkan oleh Al Baihaqi, Ibnu Asakir dan Al Thahawi.

3. Bunuh diri Sebagaimana dijelaskan oleh Imam Shalahuddin Al Jalili adalah membunuh diri sendiri yang juga merupakan gambaran dari keputusasaan yang sudah mencapai titik klimaks. Sepertinya, sudah tidak ada harapan hidup lagi, juga tidak ada kebahagiaan yang bisa diraih. Karena itu bunuh diri sebagai jalan keluarnya.

4. Bunuh diri Muhammad Adam Hussein sering kali terjadi karena beberapa alasan: Depresi, Tekanan Emosi, Tidak berani menghadapi kenyataan hidup, Miskin Harta, Miskin Ilmu dan Miskin Iman, Penyalahgunaan Barang Haram.

5. Dibolehkannya melakukan atau mengonsumsi sesuatu yang jelas-jelas di haramkan oleh Allah Swt dan Rasul-Nya yaitu ketika dalam keadaan darurat atau terpaksa dan tiada pilihan lain. 
6. Pengertian darurat atau dalam bahasa arabnya dharurah menurut Jalaluddin al Suyuthi adalah seseorang mencapai batas bila tidak memakan sesuatu yang dilarang, maka ia akan mati atau mendekati mati. Dan kondisi ini membolehkannya memakan barang haram.

7. Bolehnya melakukan sesuatu yang diharamkan sebelumnya adalah ketika dalam keadaan darurat dengan beberapa ketentuan, yang singkat penulis menyimpulkan bahwa hendaknya perbuatan yang dilakukan tersebut tidak lebih berat mudahratnya (lebih ringan) dari yang ditinggalkan.

8. Tiada alasan bagi seseorang yang mengakhiri hidupnya dengan cara bunuh diri dengan apapun alasannya. Karena besarnya alasan untuk melakukan perbuatan tersebut tidak sebanding dengan apa yang akan ia rasakan ketika berhadapan Allah Swt., di hari yang dijanjikannya kelak.

Sangaji Jurnal Pemikiran Syariah dan Hukum 


\section{Daftar Pustaka}

Al Ḥaramain, al Syarifain Khadīm. 1971. Al Qur'an dan Terjemahan Maknanya. Madinah al Munawwarah: Lembaga Percetakan Al Qur'an Raja Fahd.

Anas, Muhammad. 2015. Bunuh Diri Menurut Emile Durkhem Dalam Pandangan Agama Islam dan Pencegahannya. Jurnal Review Pendidikan Islam, Volume 02, Nomor 01, Juni 2015.

Nasution, Mawaddah. 2017. Pendidikan Agama dan Kasus Bunuh Diri

Di Kalangan Remaja. Prosiding Seminar Hilirisasi Penelitian Untuk Kesejahteraan Masyarakat Lembaga Penelitian Universitas Negeri Medan, 28 September 2017.

Al Suyuthi, Jalaluddin. 1403 H. Al Asybah wa al Nazha'ir. Beirut: Dar al Kutub al Ilmiyah.

Zuhaili, Wahbah. 1996 Ushul Figh Al Islami. Damaskus, Dar al Fikri. Dahlan, Abdul Aziz. 1997. Ensiklopedia Hukum Islam. Cetakan I. Jakarta: PT. Ihtiar Baru Van Hoeven.

Kafawi Ridwan, et al. 1993. Ensiklopedia Islam. Jakarta, PT. Icgtiar Baru van Hoeven.

Bin Ghanim, Al Sadlan dan Shalih. 1418 H. Al Qawaid al Fiqhiyyah al Kubra wa Ma Tafarra'a 'Anh. Cetakan I. Riyadh: Dar Balnasiyah.

Bin Ishaq, Al Sheikh Abdullah bin Muhammad bin Abdurrahman. 2005. Tafsir Ibnu Katsir Juz III, Tajm. M. Abdul Ghaffar dkk.

Cetakan IV. Jakarta: Pustaka Imam Syafi'i.

https://muslim.or.id 